\title{
A tribute to Nina Sergeevna Golubkova (1932-2009)
}

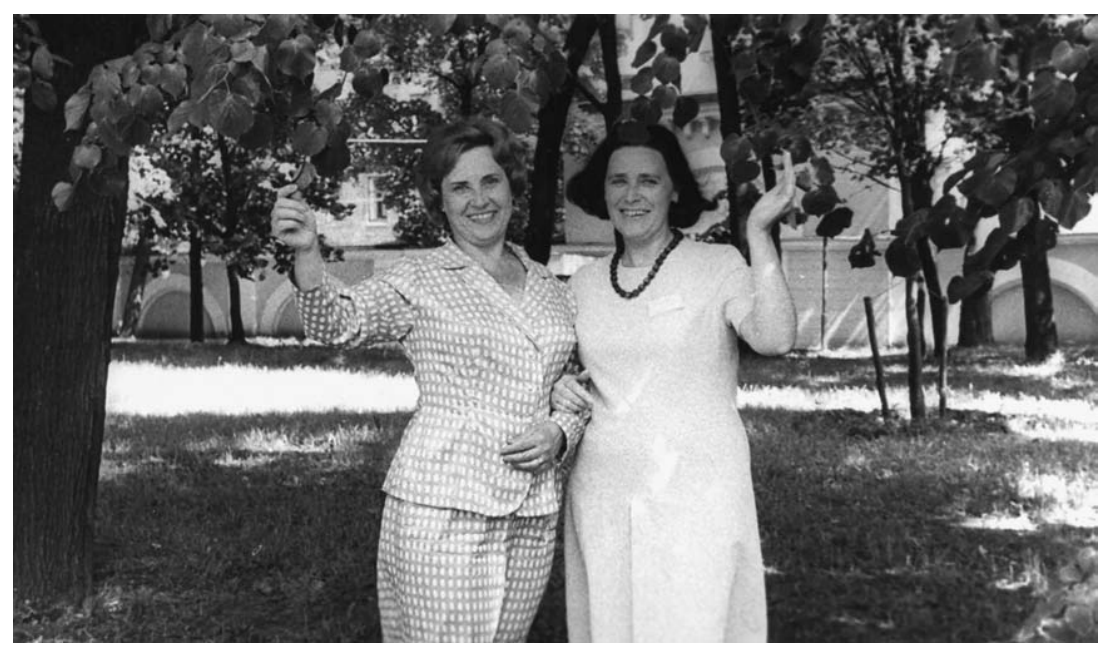

Nina Golubkova (right) with Ukrainian lichenologist Eugeniya Kopachevskaya at the time of the Botanical Congress in Leningrad, 1975. Photograph by Oleg Blum.

On 24 August 2009, Nina Golubkova, Russia's leading lichenologist for more than three decades, died in St-Peterburg. Her major contribution to lichenology was acknowledged by the Acharius medal of the IAL awarded to her in 2000 . Her scientific career was always connected with the Komarov Botanical Institute, within the Russian (formerly Soviet) Academy of Sciences, where she rose from a junior scientific researcher to become Head of the Lichenology and Bryology Laboratory in 1982.

In 1955, after graduating from the Biology Faculty of the Leningrad State University, where she specialized in mycology, she came to the Komarov Botanical Institute hoping for employment there. Luckily a research position (equivalent to a $\mathrm{PhD}$ studentship) became available under the supervision of Professor Vsevolod P. Savicz, one of the foremost lichenologists of the USSR and a student of Alexander A. Elenkin, the father of Russian lichenology. This is how Nina came to lichenology, maintaining the excellent line of those who established the subject in Russia. In 1962, Nina defended her Candidate of Sciences thesis 'The lichen flora of the Moscow region'; some of this work was incorporated into her book published in 1966 entitled 'Handbook of the Lichens of the Middle Regions of the European Part of the USSR' which for those studying lichens at that time, such as one of us (LGB), was the main identification manual on the lichens of European Russia.

In the 1950s, Nikita Khrushchov initiated exploration of the Antarctic by the USSR, some of the expeditions being responsible for gathering biological collections, including lichens. This was a reason why Nina and Vsevolod Savicz commenced work in the 1960s on Antarctic lichens, resulting in a number of publications, including descriptions of several new species: Acarospora petalina N. S. Golubk. \& Savicz, Caloplaca nigrescens N. S. Golubk. \& Savicz, Gasparrinia arctica N. S. Golubk. \& Savicz, Gyrophora 
korotkeviczii N. S. Golubk. and Physcia caesioides N. S. Golubk. \& Savicz.

In the 1960s, Nina made several field trips to the Pamir Mountains in Tadzhikistan, which was at that time part of the USSR, and where the Soviet Academy of Sciences had a research station. Nina, who generously acknowledged the help of Professor Alfred $\mathrm{N}$. Oxner in the identification of this exotic lichen flora, described several new species: Acarospora frigidodeserticola N. S. Golubk., A. gyrosa N. S. Golubk., Catapyrenium altimontanum N. S. Golubk., Dermatocarpon pamiricum N. S. Golubk., Gonohymenia reophila N. S. Golubk., Leptogium fruticulosum N. S. Golubk., Pyrenocollema occidentalipamiricum N. S. Golubk. \& Bredkina, Sporastatia subasiatica N. S. Golubk. and Squamarina pamirica N. S. Golubk. The work was summarized in 'Index systematicus lichenum Pamiri Orientalis primus' (1973). Special attention in these studies was devoted to aquatic lichens, particularly those submerged in mountain streams, resulting in the description of two new species Polyblastia intermedioides N. S. Golubk. and Staurothele aquatica N. S. Golubk. published as 'De lichenibus nonnullis submersis in fluminibus regionis altimontanae Pamiri Orientalis inventis notula' (1973).

In the 1970s, Nina began studying Mongolian lichens as part of a long-term Soviet Academy of Sciences programme of Soviet-Mongolian expeditions. Together with Professor Valerii Grubov, the well known botanist-explorer of Central Asian vascular plants, and the novice Mongolian lichenologist, U. Tsogt (Cogt), they crossed Mongolia on a track from taiga areas of Prihubsugul'e in the north to the waterless Gobi desert in the south, and from the mountains of Mongolian Altai in the west up to the Khalkhin-Gol River at the boundary with China in the east. These studies resulted in many publications, including two monographs 'Synopsis of the Lichen Flora of the Mongolian People's Republic' (1981) and 'An Analysis of the Lichen Flora of Mongolia' (1983) and descriptions of two new lichen species Acarospora fulva N. S. Golubk. and Toninia gobica N. S. Golubk. In 1983, Nina defended her Doctor of Sciences thesis 'Floragenetic analyses of lichens of Mongolia'.

Nina developed a special interest in Acarosporaceae, Umbilicariaceae and Usnea, resulting in her monograph 'The Lichen Family Acarosporaceae in the USSR' (1988), the section on the Umbilicariaceae (in coauthorship with V. P. Savicz) in 'Handbook of the Lichens of the USSR' (Issue 5, 1978) and the section on Usnea in 'Handbook of the Lichens of Russia' (Issue 6, 1996). It was Nina who inspired and ensured the continuation of the 'Handbooks of the Lichens of the USSR' in post-Soviet Union Russia and made it possible to complete this monumental task. In all, ten volumes were produced, with Nina as Editor-in-Chief of the last five (Vols 6-10, 1996-2008). Nina was also the Editor of Volumes 28-35 of 'Novitates Systematicae Plantarum non Vascularium', the main publication outlet for most Russian lichenologists.

With her considerable experience of fieldwork in various bioclimatic regions, Nina had a special interest in morphological adaptations of lichens to different ecological conditions and in the evolution of lichen biomorphs. She created an original system for the classification of lichen life-forms based on a hierarchy of division, type, class, group and forma, as most ably demonstrated in 'An Analysis of the Lichen Flora of Mongolia' (1983).

Nina readily shared her experience and knowledge, her large personal library, her hospitality and work place in the lichen herbarium of the Komarov Botanical Institute. Despite all her other interests, she managed the collections at the Institute, the largest herbarium in the USSR/Russia, most efficiently and it became a real Mecca for all lichenologists from Russia and elsewhere. She collaborated with many lichenologists, and became, for example, a co-author with T. Piin, M. Zhurbenko and T. Makryi on lichen species described from various regions of Russia: Acarospora putoranica N. S. Golubk. \& Zhurb., Biatorella contigua N. S. Golubk. \& Piin, and Strangospora selengensis Makryi \& N. S. Golubk. Her openness, welcoming attitude and administrative support attracted lichenologists to the Komarov 
Botanical Institute, such as M. Andreev, A. Titov, M. Zhurbenko, A. Dobrysh and Yu. Kotlov, as well as many students of lichenology, to work with her; she also supervised more than 20 Candidates of Science and three Doctors of Science. Her analysis of the lichen flora of Mongolia (1983) provided a standard for most Russian floristic lichenological theses.

In retirement, Nina planned to devote her time to the study of Aspicilia, based on her extensive collections from the mountainous and arid regions of Central Asia. Unfortunately these plans were not realized as she sadly succumbed to a prolonged illness. For some of us (such as MRDS), our meetings were all too infrequent, but we never lost contact, mainly due to her kind letters and generosity in providing us with literature and herbarium material, and in identifying our difficult specimens. Nina was, without doubt, an outgoing, life-loving person with exquisite taste; perhaps it was her mother, a theatrical dressmaker, who influenced Nina's good dress sense. There will come a time when there are few people alive who knew her personally and communicated with her, but for many future generations of lichenologists her name will continue to remain familiar through her published works, her described taxa, her extensive collections of herbarium material and the lichens Chaenothecopsis golubkovae Tibell \& Titov and Catillaria golubkovae Kotlov named after her. More detailed biographical information and lists of her publications are to be found in the Botanicheskii Zhurnal [Botanical fournal] 77 (10): 91-97 (1992) and in 87 (9): 144147 (2002) [in Russian].

Lev G. Biazrov, Mikhail P. Zhurbenko and Mark R. D. Seaward 
